\title{
MIGRACJE KOBIET \\ INTEGRACJA MIĘDZYKULTUROWA POLSKICH KOBIET \\ Z MAŁŻEŃSTW MIESZANYCH W WIELKIEJ BRYTANII \\ W KONTEKŚCIE STRESU AKULTURACYJNEGO
}

\section{Urszula Walczak*}

Abstrakt

Migracje kobiet wpisują się w kontekst globalnych zmian politycznych, gospodarczych i społecznych. Zjawisko rosnącej feminizacji migracji uwarunkowane jest większą świadomością kobiet, ich emancypacją, a także autonomicznością. W dobie globalizacji zawieranie małżeństw mieszanych jest dość powszechne i stanowi interdyscyplinarny obszar badawczy wielu naukowych opracowań.

Słowa kluczowe: migracje kobiet, integracja międzykulturowa, akulturacja, stres akulturacyjny, małżeństwa mieszane

\section{WOMEN'S MIGRATION}

INTEGRATION OF INTERCULTURAL POLISH WOMEN OF MIXED MARRIAGE

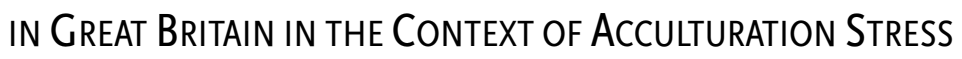

\section{Abstract}

Women's migrations are part of the context of global political, economic and social changes. The phenomenon of the growing feminisation of migration conditioned by a greater awareness of women, their emancipation, as well as autonomy. In the era of globalization, entering into marriages mixed is quite common and an interdisciplinary area researching many scientific studies.

Keywords: migrations of women, intercultural integration, acculturation, acculturational stress, mixed marriages

\footnotetext{
*Mgr Urszula Walczak, Polski Uniwersytet Na Obczyźnie w Londynie, e-mail: urszula.walczak@puno.edu.pl | ORCID: https://orcid.org/0000-0002-9838-5417
} 
Wprowadzenie

Upadek bipolarnego systemu stosunków międzynarodowych oraz doktryny komunistycznej znacznie przyśpieszył proces globalizacji, której ważnym elementem obok liberalizacji przepływów towarów, usług i kapitału stały się migracje ludności (Deszczyński 2011). Globalizacja przepływu informacji o zjawisku migracji powoduje, że podejmowanie decyzji o emigracji staje się coraz łatwiejsze poprzez funkcjonowanie ogólnoświatowego systemu troski o prawa imigranta i jego rodziny.

Od momentu wstąpienia Polski do Unii Europejskiej rozpoczęły się masowe emigracje Polaków do Wielkiej Brytanii. Według danych brytyjskiego Brytyjskiego Urzędu Statystycznego na terenie Wielkiej Brytanii żyje obecnie około 1 miliona Polaków. Kraj ten jest międzykulturową metropolią pod względem liczby jej ludności odnoszącej się do kraju urodzenia i narodowości.

Ludzie emigrują do innych krajów z różnorodnych powodów. Jedni robią to ze względu na chęć przeżycia przygody, inni z powodów ekonomicznych, edukacyjnych, a jeszcze inni w celu ucieczki przed wojną czy prześladowaniami (Garapich 2008). Według Aliny Witkowskiej (1997) emigracja jest najwyższą ceną, jaką należy zapłacić za zachowanie ludzkiej wolności.

Celem artykułu jest zwrócenie uwagi na zjawisko integracji polskich kobiet z małżeństw mieszanych, w kontekście stresu akulturacyjnego na terenie Wielkiej Brytanii. Kobiety, które znajdują się w nowym środowisku, zwykle poddawane są złożonym i długotrwałym procesom adaptacyjnym, będąc często wręcz zmuszane do przyjmowania obcych tradycji i obyczajów. Niejednokrotnie stykają się z nieznanymi im do tej pory wartościami i normami społecznymi. Konfrontacja z nową rzeczywistością może doprowadzić do nieprzewidywalnych zachowań, zarówno ze strony emigrantek, jak i członków społeczeństwa przyjmującego. 
Podjęta tematyka badawcza jest niezmiernie ważna i aktualna. Wskazuje na istotę relacji pomiędzy poziomem integracji międzykulturowej polskich kobiet z małżeństw mieszanych w Wielkiej Brytanii, a zjawiskiem stresu akulturacyjnego. Przedstawiony temat ma wymiar nie tylko jednostkowy czy grupowy, ale również światowy.

Migracje w literaturze przedmiotu

Wyraz „migracja” pochodzi z łacińskiego migratio i oznacza wędrówkę lub wędrowanie. Dawna interpretacja tego zjawiska odnosiła się do terminu „emigracja” lub „imigracja”. Współcześnie migracja łączy ze sobą te dwa terminy (Kubitsky 2012). Migracje międzynarodowe to przemieszczanie się ludzi z jednego kraju do drugiego na pobyt okresowy lub stały, dobrowolnie lub pod przymusem.

$\mathrm{Z}$ punktu widzenia państwa migracje międzynarodowe obejmują dwa procesy: emigrację, która oznacza opuszczenie kraju i imigrację, czyli dopływ cudzoziemców na jego terytorium. Każde przekroczenie granicy państwa w celach turystycznych, rodzinnych, zawodowych, religijnych, podjęcia pracy, osiedlenia się z przyczyn politycznych czy ekonomicznych jest elementem migracji międzynarodowych (Mały stownik stosunków międzynarodowych 1996).

Migracja jest szczególna formą kryzysu. To stan dezorientacji, który wymaga zarówno przebudowy wewnętrznej, jak i zewnętrznej. Spotkanie z obcym krajem zmusza do konfrontacji z nowym środowiskiem i zarazem do refleksji nad własnym życiem. Przepracowanie tych odczuć i myśli wymaga czasu. Okres dochodzenia do równowagi jest długi, chwilami nawet bolesny (Kubitsky 2012).

Migracje przyczyniają się do zmian społecznych i ekonomicznych w świecie. Mogą być dobrowolne, wynikające $\mathrm{z}$ własnej decyzji, lub przymusowe, wynikające z problemów ekonomicznych, politycznych czy religijnych. Czynniki, które skłaniają jednostkę do podjęcia decyzji 
o migracji, można podzielić na tzw. pobudki „wypychające”, które zachęcają jednostkę do wyjazdu i obejmują czynniki ekonomiczne, prawne, demograficzne, a także społeczno-polityczne oraz na bodźce „przyciągające”, które mają wpływ na wybór miejsca emigracji i uwzględniają czynniki historyczne, ekonomiczne, prawne oraz społeczno-ekonomiczne (Sakson 2001).

W nowożytnej historii polskiej migracji do Wielkiej Brytanii wyróżnia się trzy istotne wydarzenia: przesiedlenia polskiego korpusu wojskowego po II wojnie światowej, przybycie nielegalnych pracownikówimigrantów w latach 90. zeszłego wieku i emigrację na dużą skalę po tym, jak Polska stała się członkiem Unii Europejskiej (EU). Był to początek nowego etapu w historii migracji. Głównymi motywami skłaniającymi Polaków - już jako obywateli UE do emigracji - były najczęściej lepsze zarobki, warunki pracy, wyższy standard życia, możliwość zdobycia doświadczenia, spotkania nowych ludzi, pozytywne doświadczenia innych osób, lepsze możliwości zrobienia kariery niż we własnym kraju oraz brak poprawy sytuacji ekonomicznej w Polsce (Bera, Korczyński 2012).

Od kiedy Polska przystąpiła do UE, wyjechało z kraju ponad 2,21 miliona osób, głównie do Wielkiej Brytanii, Irlandii, Niemiec i Szwecji (Bera 2011). Główny Urząd Statystyczny (2011), opierając się na wynikach Narodowego Spisu Powszechnego z roku 2011, wskazuje, że pod koniec 2011 za granicami kraju przebywało 2017500 osób, które wyjechały czasowo lub na stałe po przystąpieniu Polski do Unii Europejskiej. Stanowiło to ponad 5\% ogólnej liczby ludności Polski, szacowanej na 38 500 ooo. Emigruje nieco więcej kobiet niż mężczyzn (52\% versus 48\%). Ponad 60\% emigrantów to osoby w wieku pomiędzy 20, a 39 rokiem życia. 45\% jest w związkach małżeńskich, a $34 \%$ to single. 
Feminizacja migracji

Według Międzynarodowej Organizacji Migracji, kobiety stanowią około 48,4\% wszystkich międzynarodowych migrantów. Wśród krajów o największej reprezentacji kobiet-migrantek jest Nepal, Mołdawia, Czarnogóra, Łotwa i Hongkong (International Organization for Migration Slovak Republic b.r.).

Początkowe migracje kobiet polegały na podążaniu za mężem czy ojcem, co nadawało im status społeczny żony lub córki. To mężczyźni dominowali w migracjach, a ich wiodąca rola wynikała $\mathrm{z}$ dominującego wówczas modelu rodziny. W latach 80 . XX wieku sytuacja uległa zmianie, gdyż nastąpił rozwój samoświadomości kobiet, które zaczęły dostrzegać swój potencjał i swoją siłę w samodzielnej migracji zarobkowej (Kawczyńska-Butrym 2009). Rola kobiet w procesach migracyjnych zdecydowanie ulega zmianie (Pasamonik 2008).

Charakterystyczną cechą naszych czasów jest skala oraz dynamika emigracji zarobkowej kobiet. Feminizacja migracji wynika często z przymusu ekonomicznego. Wpływa na redefinicję roli kobiet w życiu rodziny: to one stają się odpowiedzialne za utrzymanie najbliższych. Poszukując źródła utrzymania w innym kraju, kobiety jednocześnie dążą do zmiany swojego otoczenia społecznego. Analizując to zjawisko należy też zwracać uwagę na warunki w krajach, które opuszcza więcej kobiet niż mężczyzn, motywy wyjazdu kobiet i ich cele, rodzaj prac wykonywanych przez migrantki oraz zagrożenia wynikające z ich migracji. Migracyjne decyzje kobiet dotyczą trudnej sytuacji materialnej, braku środków do utrzymania siebie i rodziny, sprzyjających zatrudnieniu ofert krajów przyjmujących, a także bazują na potrzebach indywidualnych - tzw. wyjazdy „dla siebie” (Kawczyńska-Butrym 2009, s. 39-41).

Obecnie istnieje wiele badań dotyczących migracji kobiet. Krystyna Slany i Agnieszka Małek (2005) analizowały to zjawisko w kontekście teorii traumy. Migracje w ich ujęciu zostały przedstawione jako sposób 
adaptacji do stanu anomii. Na tej podstawie autorki sporządziły typologię migrantek w oparciu o kryterium przewodnie motywu migracji. Wyodrębnione $\mathrm{w}$ procesie badawczym typy emigrantek posiadały wiele cech wspólnych oraz takie same doświadczenia. Dotyczyły one m.in. charakteru pierwszej pracy podejmowanej za granicą, utraty umiejętności, które posiadały przed wyjazdem oraz brak możliwości realnego awansu społecznego. W sytuacji migrujących kobiet zachodziła multiplikacja ról polegająca na przejęciu od mężczyzny roli żywiciela rodziny (Miłkowski 1997).

Niektóre badania wskazują na emancypację kobiet migrantek, które wywodząc się z tradycyjnych społeczeństw, stają się coraz bardziej świadome swoich praw i predyspozycji w wyniku obserwacji partnerskich relacji zachodzących między kobietą a mężczyzną poza granicami kraju. Nicolas Perrin i Helena Rajabaly (2005) na podstawie uzyskanych wyników z przeprowadzonych badań stwierdzili, że powodem feminizacji polskiej emigracji w Belgii jest nie tylko podaż pracy wykonywanej zwykle przez kobiety, ale również i zawierane przez nie małżeństwa polskobelgijskie. Migracja jest procesem dynamicznym i pełnym sprzeczności, który wpływa na kreowanie się ról płciowych. Tradycyjne funkcje kobiet i chęć realizacji zawodowej niejednokrotnie rozpatrywane są w kategoriach trudności ich zrealizowania.

Kraj pochodzenia migrantki ma również istotne znaczenie dla rodzaju jak i warunków jej pracy. Zofia Kawczyńska-Butrym (2009, s. 40) uważa, że państwa, z których wyjeżdżają emigrantki charakteryzują się „niższym niż w bogatych krajach poziomem rozwoju ekonomicznego i powiązanymi z nim problemami na rynku pracy, trudnościami materialnymi rodzin i niskim standardem ich życia, niższym niż w krajach bogatych o dynamicznie rozwijających się gospodarkach”.

Przeprowadzone przez Shigehiro Oishi badania (za: Ghosh 2009) wskazały na znaczące różnice w wysokości wynagrodzenia, jak i charakteru wykonywanych czynności w zależności od kraju, z którego wywodziły 
się migrantki. Emigracja zarobkowa kobiet stwarza ograniczone możliwości ich awansu w wyniku segmentacji rynku pracy oraz niskiego statusu zajęć przez nie podejmowanych.

Wśród tematów badawczych nad emigracją kobiet znajdują się także sezonowe wyjazdy. Migrantki decydowały się na podjęcie pracy sezonowej głównie ze względów ekonomicznych oraz chęci wzbogacenia kapitału społecznego oraz kulturowego (Szczygielska 2013).

Migracje kobiet niosą za sobą konsekwencje tych wyjazdów nie tylko dla nich samych, ale również i dla ich rodzin. Aktywność zawodowa kobiet z krajów wysoko rozwiniętych doprowadziła do pewnego rodzaju zaniedbania funkcji opiekuńczej rodziny, generując przy tym zapotrzebowanie na usługę prac domowych, opieki nad dziećmi czy osobami starszymi. Takie zadania wykonują przeważnie migrantki. Praca w domu umożliwia migrantkom kontrolę rytmu pracy oraz adekwatne dostosowanie jej do własnych możliwości. Helma Lutz (2004) w swoich badaniach wymienia cztery kategorie kobiet, które podejmują tego typu prace. Wyróżnia młode kobiety, które chcą zdobyć nowe kwalifikacje, pieniądze na opłatę kosztów kształcenia oraz kobiety rozwiedzione i poszukujące nowego partnera, dążące do zdobycia środków finansowych na pokrycie potrzeb rodziny. Kolejne grupy stanowią kobiety posiadające rodziny, które poszukują źródeł dochodu oraz kobiety o innej orientacji seksualnej, uciekające z kraju przed dyskryminacją.

Początki pracy migrantek dotyczą głównie zatrudnienia u jednego pracodawcy. Według Bridget Anderson (2000) ich obowiązki zamykają się w tak zwanym „3C”, co oznacza sprzątanie (cleaning), gotowanie (cooking) i opieka (caring). Jak określa Vaiou (2002), sprzątanie domów to praca w kategoriach „3D”, czyli wymagająca (demanding), brudna (dirty) i niebezpieczna (dangerous). Mechanizm ten sprawia, że braki w polityce społecznej państw wysoko rozwiniętych negatywnie wpływają na strukturę rodzin w krajach emigracji. Wyniki badań Iryny 
Kyzymy (2007) wskazują na negatywne skutki migracji, które spowodowane między innymi przez kryzys demograficzny jaki panuje w kraju migrantek, dewaluacją ich umiejętności i kwalifikacji oraz trudne warunki pracy za granicą, niekorzystnie wpływają na stan ich zdrowia fizycznego i psychicznego.

Camille Schmoll (2005) swoje badania opiera na analizie przemian tożsamości kobiet na skutek migracji. Twierdzi, iż migracja wpływa na umocnienie pozycji kobiet mimo niesprzyjających oraz płciowo uwarunkowanych obowiązków, jak i trudności. Płeć migranta niewątpliwie określa konsekwencje jego migracji. W przypadku kobiet, często ich płeć jest czynnikiem, który wywołuje negatywne skutki migracji. Niejednokrotnie są wykorzystywane, doświadczają przemocy, dyskryminacji lub określonej postawy wobec grupy migrantów. Muszą zmierzyć się z problemami bycia kobietą i bycia obcym.

Należy zwrócić przy tym uwagę na fakt, iż płeć nie funkcjonuje w oderwaniu od etniczności, rasy i wyznania (Martin 2007). Kobiety narażone są także na przykre zmiany relacji rodzinnych, co niejednokrotnie spowodowane jest faktem pozostawienia w kraju swoich dzieci. Badania Danuty Mostwin (1991) wskazują, że kryzysy rodzinne powstałe na skutek emigracji są wynikiem oddziaływania różnorodnych stresów. Zalicza do nich tzw. przeszczepienie czyli zmianę otoczenia geograficznego i kulturowego czego konsekwencją jest utrata kraju pochodzenia. Zwraca uwagę na rozdzielenie i łączenie rodzin, zmiany i fragmentaryzację ról rodzinnych oraz podwójną socjalizację dziecka, czy korzystanie z używek.

Migracje kobiet mogą także pomóc im w przejściu przez różne szczeble społeczno-gospodarcze. Wiele imigrantek korzysta z możliwości zakupu ziemi lub nieruchomości, ma tendencję do przekazywania większej części zarobków na gospodarstwo domowe niż mężczyźni i sprawowania kontroli nad dochodami. Migracja w coraz większym stopniu oferuje kobietom możliwości edukacji i kariery zawodowej, a także jest 
alternatywą dla zawarcia związku małżeńskiego (Global Perspectives on Migration and Development. GFMD Puerto Vallarta and Beyond (2012).

Akulturacja jako proces adaptacji kulturowej

Istotnym elementem migracji jest akulturacja, która zajmuje się zjawiskami wynikającymi ze spotkania się grup o różnym pochodzeniu etnicznym i odmiennych wizjach świata (Kluź 2001). Według definicji Międzynarodowej Organizacji do Spraw Migracji, akulturacja jest procesem zmian kulturowych, jakie zachodzą w wyniku bezpośredniej i długotrwałej konfrontacji odmiennych systemów kulturowych, które prowadzą do stopniowych zmian w jednym lub we wszystkich wchodzących $\mathrm{w}$ interakcję systemach. W przypadku migrantów jest to szeroko pojęta przemiana wzorów kulturowych, która dokonuje się pod wpływem uczestnictwa w różnych formach życia społeczno-kulturalnego kraju osiedlenia; przejmowanie przez jednostkę lub grupę kultury innej grupy etnicznej.

Według Johna Berry’ego (2003), akulturacja psychologiczna odnosi się do zmian jakie zachodzą w jednostce uczestniczącej w sytuacji kontaktu kulturowego i odczuwającej bezpośredni wpływ zewnętrznej kultury oraz zmiany w kulturze w której uczestniczy.

Akulturacja definiowana jest również jako wynik bezpośredniej transmisji kulturowej, która może mieć przyczyny nie-kulturowe, na przykład ekologiczne lub demograficzne modyfikacje wywołane na skutek zderzenia się kultur. Może być również konsekwencją przyjęcia obcych wzorów zachowania jako własnych oraz może stanowić reaktywne dopasowanie sposobu życia jednostki (Berry, Sam 2006).

Paweł Boski (2010, s. 505) twierdzi, że „o akulturacji psychologicznej mówimy, gdy osoba wywodząca się z określonego systemu kulturowego (A) i ukształtowana przezeń znalazła się w polu relatywnie długich 
i intensywnych oddziaływań innej kultury (B), które muszą i/lub inicjują spontaniczne procesy adaptacyjne prowadzące do zmian w funkcjonowaniu psychologicznym o różnym stopniu przystosowalności".

Przebieg procesu akulturacji cudzoziemców zdeterminowany jest wieloma czynnikami, które często utrudniają migrantom przystosowanie się do nowej kultury. Zalicza się do nich: nieznajomość kultury kraju przyjmującego, nieznajomość reguł i zasad panujących w danym środowisku społecznym, nieznajomość języka, brak wsparcia społecznego, dystans kulturowy, wcześniejsze doświadczenia oraz polityka państwa przyjmującego.

Samoświadomość jednostek może być rozwinięta u nich w różnym stopniu co przekłada się na jakość ich kompetencji komunikacyjnych i adaptacyjnych. Według Moniki Chutnik (2007), brak kompetencji językowych może spowodować silne negatywne emocje czego konsekwencją będzie negatywny stosunek do kraju przyjmującego. Adrian Furnham, Stephen Bochner i Colleen Ward (2001) wyróżniają psychologiczne oraz socjo-kulturowe przystosowanie się do nowej kultury. Pierwsze odnosi się do życia wewnętrznego jednostki i obejmuje poczucie własnej wartości, kulturową i własną tożsamość, pozytywne zdrowie psychiczne oraz satysfakcję z nowego kontekstu kulturowego. Natomiast drugi rodzaj przystosowania dotyczy dostosowania sił do nowego kontekstu kulturowego, umiejętności radzenia sobie z problemami dnia codziennego, zdolności do pokonywania problemów w życiu zawodowym czy rodzinnym.

Najczęściej spotykaną koncepcją akulturacji, która opisuje wzorce przystosowania do funkcjonowania w środowisku odmiennym niż kultura pochodzenia, jest model Berry'ego. Podkreśla on znaczenie społeczeństw multikulturowych, grup mniejszościowych oraz uznaje prawo jednostek do określania jak daleko są w stanie posunąć się w procesie akulturacji. Wyróżnia cztery strategie, które są mniej lub bardziej dobrowolnie wybierane przez osoby lub grupy podlegające temu 
procesowi. Są wynikiem ustosunkowania się do dwóch kwestii: czy warto podtrzymywać swoja dotychczasową tożsamość kulturową? oraz czy warto uczestniczyć w kulturze przyjmującej? W zależności od odpowiedzi udzielonej na każde z tych pytań możliwe są cztery opcje, tzw. cztery główne strategie akulturacyjne: integracja, asymilacja, separacja i marginalizacja.

Integracja zakłada utrzymanie integralności kulturowej grupy włączającej się w społeczeństwo przyjmujące przy jednoczesnym dążeniu by stać się integralną częścią nowej struktury społecznej (Berry 1997). Jest ona przede wszystkim rezultatem indywidualnych wyborów, ale także procesem, który zachodzi do pewnego stopnia spontanicznie. Terminem integracja określa się zarówno proces zmian stosunków między imigrantem a społeczeństwem przyjmującym, ale także jego rezultat, czyli stan stosunków społecznych osiągnięty na skutek procesu integracji.

Według Międzynarodowej Organizacji Migracji (International Organization for Migration 2015), integracja jest dwustronnym procesem wzajemnej adaptacji imigrantów i społeczeństwa w wymiarze ekonomicznym, społecznym, kulturowym i politycznym. Strategia integracji związana jest z pozytywnym stosunkiem i chęcią podtrzymywania własnej identyfikacji kulturowej przy jednoczesnym utrzymywaniu kontaktu ze społeczeństwem przyjmującym. Opiera się na współpracy z przedstawicielami obu kultur, na osiąganiu stawianych celów w sferze zawodowej i prywatnej. Kontakty z przedstawicielami obu kultur przebiegają z poczuciem obustronnego zrozumienia. Strategia ta nie jest łatwa do osiągnięcia, ponieważ wymaga od jednostki dużej motywacji, wysiłku oraz zmusza do czynnego udziału w życiu społecznym kraju osiedlenia.

Asymilacja wyznacza natomiast stopniowe przyjmowanie zasad, norm, wartości, tradycji oraz wzorów zachowań jakie panują w kulturze przyjmującej, przy jednoczesnym przekreślaniu dotychczasowej tożsamości kulturowej. Wybór tej strategii ogranicza kontakty z osobami 
z własnej kultury, gdyż są one źródłem negatywnych odczuć lub przeżyć. Może towarzyszyć temu niechęć wobec kultury pochodzenia, negatywna jej ewaluacja, nieużywanie własnego języka, a nawet świadome wypieranie się swojego pochodzenia oraz zaprzeczanie mu.

Kolejna strategia - separacja - oznacza brak uczestnictwa w kulturze przyjmującej i funkcjonowanie w środowisku kultury pochodzenia. Jednostka ogranicza do koniecznego minimum kontaktów z kultura przyjmującą, z przewaga emocji negatywnych. Broni swojej kultury i tożsamości, nieustannie ją podkreśla i wyróżnia, tracąc przy tym zainteresowanie kulturą kraju przyjmującego. Ostatnią strategią, najmniej korzystną jest marginalizacja, która odcina jednostkę od kultury jej pochodzenia, jak i kultury przyjmującej. Osoby wybierające tą strategię charakteryzują negatywne emocje w kontaktach z obydwoma środowiskami lub brak kompetencji do funkcjonowania w nich, brak satysfakcji z wykonywanej pracy z powodu braku kompetencji lub umiejętności współpracy z ludźmi, wycofywanie się z kontaktów, a także zachowania destruktywne takie jak uzależnienia, czy udział w świecie przestępczym (Berry 1995).

Istotnym czynnikiem wewnętrznym dla integracji z obcą kulturą jest stopień identyfikacji z kulturą własną i odpowiednio ukształtowane w niej poczucie tożsamości (Wallas 2008). Dominującym pojęciem współczesnych dyskusji europejskich na temat imigrantów jest pojęcie integracji, które w ograniczonym stopniu uwzględnia zagadnienia dotyczące tożsamości oraz psychologicznej adaptacji imigrantów. Tożsamość człowieka jest zjawiskiem złożonym, co wynika z wieloaspektowości i specyficzności „Ja”. Jest procesem, podczas którego podlega ustawicznym przemianom w trakcie rozwoju jednostki. Ściśle wiąże się z systemem wartości, światopoglądem, przywiązaniem do tradycji oraz z cielesnością człowieka, kolorem skóry czy rasą. Rozwój tożsamości następuje w oparciu o relacje społeczne i więzi emocjonalne w odniesieniu do konkretnej grupy w kontekście społeczno-kulturowym. 
Można wyróżnić tożsamość: osobistą - aspekty „Ja” związane są ściśle z osobowością człowieka, społeczną - aspekty „Ja” związane są z przynależnością człowieka do grupy społecznej, narodową - aspekty „Ja” związane są z poczuciem więzi jednostki z własnym narodem oraz kulturową, czyli świadomość przynależności do własnej grupy kulturowej w odniesieniu do tradycji, odrębności etnicznej, sposobów myślenia, zachowania, działania oraz współdziałań zgodnych z konkretnymi wartościami i normami (Filipek 2008).

Zbigniew Bokszański (1989) twierdził, że tożsamość jest pojęciem wieloznacznym, które wynika z fundamentalnej i coraz bardziej niezrozumiałej oraz złożonej relacji, jaka zachodzi między jednostką, a społeczeństwem. Główną własnością tożsamości jest możliwość łączenia różnorodnych elementów, przy czym jednostka dąży do określenia się, ugruntowania oraz do pewnej spójności. Istotnym elementem tożsamości jest także samoświadomość jednostki, poczucie jej niepowtarzalności i odrębności oraz przynależności i własnej wartości.

Koncepcja społecznego zakotwiczenia według Aleksandry GrzymałyKazłowskiej (2013) odnosi się do kwestii tożsamościowych oraz uwzględnia czynniki zewnętrzne i obiektywne, czyli takie, które osadzają jednostkę w danej rzeczywistości. Łączy zagadnienia tożsamościowe z problematyką dotyczącą adaptacji jednostki, jak i jej złożonych związków ze społeczeństwem, czyli integracji społecznej. Poprzez „zakotwiczenie" rozumie poszukiwanie przez imigrantów ważnych dla nich tzw. kotwic, które pozwolą na określenie miejsca w danej społeczności oraz osiągnięcie relatywno-psychologicznej stabilności w nowych warunkach życia. Autorka zwraca uwagę na integrację w kontekście uczestnictwa imigrantów w różnych obszarach życia społeczeństwa przyjmującego. Wskazuje na ich związki nie tylko ze społeczeństwem przyjmującym, ale także w pewien sposób na współdzielenie przez nich kultury z mieszkańcami danego kraju. 
Koncepcja społecznego zakotwiczenia łączy zagadnienia tożsamości oraz więzi społecznych. Wskazuje, w jaki sposób imigranci adaptują się i integrują w społeczeństwie przyjmującym oraz jaką przyjmują rolę tożsamości. Procesom adaptacji imigrantów towarzyszą zarówno społeczno-kulturowe zmiany tożsamości, jak i przemiany ich indywidualnej tożsamości. W okresie przejściowym oraz w czasie późniejszej adaptacji do nowego środowiska te procesy tożsamościowe wykorzystywane są jako narzędzia „zakotwiczenia migrantów”. Sławomir Łodziński i Aleksandra Grzymała-Kazłowska (2011) twierdzą, iż polityka integracyjna ma istotny wpływ na koncepcję integracji, gdyż państwo przyjmujące wspiera przystosowanie migrantów do życia w nowym środowisku społecznym w celu zagwarantowania utrzymania ładu społeczno-kulturowego.

Wielokulturowość związków

Integracja międzykulturowa polskich kobiet z małżeństw mieszanych w Wielkiej Brytanii nierozerwalnie łączy się z charakterystycznym zjawiskiem XXI wieku, jakim jest wielokulturowość. Zjawisko to stanowi rezultat globalizacji, którego doświadcza większość współczesnych społeczności w różnym stopniu jej nasilenia i charakteru.

Rozumienie wielokulturowości jako prostego skupienia kultur w przestrzeni nie jest adekwatne do społecznej rzeczywistości, ponieważ wielokulturowość to przede wszystkim „zbiór zasad i procesów realizacji współżycia społecznego w warunkach realizacji pluralizmu etnicznego i kulturowego, nastawionych przy tym na optymalizację stosunków społecznych przez wyrównywanie praw i szans uczestnictwa, co pozwala na niwelację napięć i konfliktów" (Mamzer 2003, s. 33).

Istota wielokulturowości opiera się na dwóch zasadniczych wartościach: wolności, czyli możliwość kultywowania wybranej kultury, oraz równości dotyczącej prawa kultur do istnienia i rozwoju. Rozprzestrzenianie 
sfery wolności i równości prowadzi do ukształtowania społeczeństwa wielokulturowego (Sadowski 1999).

Charakterystycznym zjawiskiem takiego społeczeństwa jest zjawisko dyfuzji kulturowej, czyli pośredniego lub bezpośredniego procesu przenikania się z jednej grupy społecznej do drugiej różnorodnych cech oraz materialnych lub niematerialnych elementów kultury. Spotykanie na swojej drodze życiowej osób z odmiennych kręgów kulturowych, religijnych czy społecznych stało się częstym zjawiskiem współczesnych czasów. Taki bezpośredni kontakt z osobą należącą do innej grupy etnicznej, narodowej, do innej rasy, wyznającej odmienną religię powoduje tworzenie przez nią różnorodnych więzi w społeczeństwie przyjmującym.

W dobie globalizacji zawieranie małżeństw z osobami z różnych kultur stało się zjawiskiem dość powszechnym. Poszukiwanie współmałżonka na „międzynarodowym rynku małżeńskim” odzwierciedla oś globalnej potęgi, którą poruszają w badaniach Minjeong Kim (2010) oraz Thomas Niedomysl, John Östh i Maarten van Ham (2010). Małżeństwa między przedstawicielami różnych środowisk społecznych traktowane są jako jeden z najlepszych wskaźników integracji, a także jako przejaw zaniku dystansu społecznego. Stanowią pewnego rodzaju międzykulturowy mikroświat w którym w oparciu o proces wyrównywania różnic kulturowych dochodzi do wzajemnego przenikania się elementów obu kultur co wpływa na uruchomienie procesu dążenia do kulturowego ujednolicenia jego członków (Paleczny 2007).

Małżeństwa mieszane, międzykategorialne, heterogamiczne stanowią związki osób różniących się pod względem pochodzenia etnicznego partnerów, narodowości, rasy, religii, klasy społecznej czy kasty. Często zdarza się, że małżeństwa są mieszane pod względem więcej niż jednej z wyżej wymienionych cech. Ze względu na różne cechy małżonków literatura przedmiotu wyróżnia pewne terminy małżeństw mieszanych. Antoni Rajkiewicz (2009) wskazując na związek z mobilnością międzynarodową małżonków używa terminów: małżeństwa binacjonalne oraz 
małżeństwa transgraniczne, zwracając przy tym uwagę na związek między ich zawarciem, a migracjami międzynarodowymi.

Marzia Balzani (2006) wyodrębnia małżeństwa transnarodowe, w których zawarcie związku małżeńskiego wpływa na migrację zagraniczną jednego partnera z ich wspólnego kraju pochodzenia i podtrzymuje transnarodowe zaangażowanie kolejnych pokoleń imigrantów. Na gruncie psychologii kulturowej Grzymała-Moszczyńska (2011) stosuje terminy: małżeństwa interkulturowe, międzykulturowe, bikulturowe oraz dwukulturowe.

Zagadnienia dotyczące małżeństw mieszanych stanowią interdyscyplinarny obszar badawczy wielu naukowych opracowań. Badania nad doborem małżeńskim rozpatrywane są w kontekście kilku nurtów. Odnoszą się do obszaru demograficznego, który dotyczy poznania kryteriów, wzorów doboru małżeńskiego, praw jakie rządzą rynkiem matrymonialnym. Zmierzają do określenia trendów zawierania małżeństw mieszanych oraz przestrzeni spotkań ludzi, którzy poszukują partnerów. W badaniach psychologii kulturowej tematyka małżeństw mieszanych oscyluje wokół interakcji, ich przebiegu, przyczyn konfliktów oraz sytuacji kryzysowych i jakości tych związków. Podejmuje także problematykę tożsamości małżeństw i ich dzieci. Kolejne badania dotyczą małżeństw transnarodowych, ról genderowych i relacji władzy, jakie istnieją w takich małżeństwach.

Literatura przedmiotu koncentruje się także na badaniach dotyczących małżeństw fikcyjnych, na badaniach ukazujących społeczne konsekwencje heterogeniczności pod względem różnych cech współmałżonków oraz nad różnymi poziomami integracji migrantów którzy tworzą związki wielokulturowe. Należy zwrócić uwagę, że oprócz badań nad związkami formalnymi pojawiają się także nowe opracowania uwzględniające problematykę związków kohabitacyjnych, relacji przyjacielskich jakie zachodzą między członkami mniejszości, a społeczeństwem przyjmującym (Brzozowska 2015). 
Małżeństwo mieszane jest szczególnym związkiem, w którym dochodzi do powstania specyficznej sytuacji, jaką jest spotkanie dwojga ludzi różniących się pod wieloma względami, odległych kulturowo, którzy decydują się na zawarcie małżeństwa, wspólne pożycie, wychowywanie dzieci, współpracę dla dobra rodziny oraz wzajemną pomoc. Jordi Roca i Ana Urmeneta (2013) twierdzą, że współczesne typy związków mieszanych są raczej wynikiem świadomego poszukiwania partnera niż przypadkowego spotkania. Różnice kulturowe zachodzące między małżonkami stanowią zmienną niezależną, która determinuje wzory doboru współmałżonka oraz wpływa na jakość i trwałość małżeństwa (Jodłowska-Herudzińska 2001). Wpływają one często na obciążenie życia małżeńskiego i rodzinnego oraz prowadzą do braku zrozumienia wielu aspektów życia małżeńskiego na skutek odmiennych oczekiwań, ról w rodzinie, wartości czy komunikacji, co sprzyja powstawaniu i nasilaniu różnego rodzaju konfliktów.

Larissa Remmenick (2009) poświęca swoje badania rozwiązywaniu konfliktów w kontekście małżeństw mieszanych, sugerując, że jeden partner, zwykle reprezentujący grupę o niższym statusie społecznym, a więc zazwyczaj kobieta, stopniowo przechodziła w kierunku kultury większościowej, postrzeganej jako lepszej. Heterogomia, która dotyczy różnic małżonków w ich narodowości, rasie czy wyznaniu, jest istotnym czynnikiem wpływającym na trudności i napięcia występujące w małżeństwach mieszanych oraz prowadzi do ich dezorganizacji, a nawet rozpadu.

Małgorzata Jodłowska-Herudzińska (2002) podkreśla, że związki między partnerami pochodzącymi z różnych kultur mogą być trudniejsze, ale często tworzą emocjonalne wspólnoty, które charakteryzują się symetrią i partnerstwem. Twierdzi, że ludzie tworzący heterogamiczne związki powinni - w przeciwieństwie do etnicznie endogamicznych par - prowadzić „spotkanie” lub „zderzenie” kultur, co staje się punktem wyjścia do modyfikacji tożsamości jednokulturowej. Kobiety z małżeństw 
mieszanych wypracowują własne strategie, które chronią stabilność ich małżeństwa przed negatywnym wpływem różnic kulturowych oraz posługują się różnymi sposobami radzenia sobie ze zjawiskiem wielokulturowości. Wybierają takie strategie akulturacji, które zezwalają im na całkowite porzucenie jednej z kultur; świadome wybieranie elementów obu kultur oraz integrację ich w celu stworzenia spójnej rodziny i zbudowania określonej tożsamości.

Współczesny świat daje ludziom nieograniczone możliwości w przemieszczaniu się, a także w podejmowaniu decyzji dotyczących m.in tworzenia związków wielokulturowych oraz możliwości wyboru miejsca zamieszkania, kultury, języka czy religii. Człowiek jako istota kreatywna bierze udział we wspólnym tworzeniu danej kultury, co powoduje wśród emigrantów wiele różnorodnych trudności oraz wymaga pewnych rozwiązań. Problemy dotyczą różnych sfer życia człowieka na emigracji. Pokonywanie ich wspólnymi siłami korzystnie wpływa na osiąganie wyższego poziomu zarówno jednostki, jak i grupy. Na jakość kontaktów międzykulturowych ma wpływ obecność każdego, kto w nich uczestniczy, oraz wzajemne poznawanie, zrozumienie, zaangażowanie, a przede wszystkim zaakceptowanie poczucia wzajemnej zależności i wspólnego losu. Związki wielokulturowe stanowią pewnego rodzaju międzykulturowy mikroświat, w którym w oparciu o proces wyrównywania różnic kulturowych dochodzi do wzajemnego przenikania się elementów kultur, co uruchamia proces dążenia do kulturowego ujednolicenia jego członków (Paleczny 2007).

Konfrontacja z nową rzeczywistością może być zarówno przeżyciem bardzo pozytywnym i kształcącym, które uczy przede wszystkim tolerancji, jak również skrajnie negatywnym, powodującym stres i szok kulturowy. Istotne jest w tym wszystkim wzajemne zbliżenie, któremu sprzyjają różnorodne strategie adaptacyjne stosowane przez partnerów. Akulturacja wymaga zaangażowania i wysiłku zaradczego na poziomie zawodowym, psychologicznym, jak i fizjologicznym. Codzienne życie pełne jest różnorodnych sytuacji stresowych. W momencie, kiedy nie 
potrafimy efektywnie sobie z nimi poradzić, wówczas mogą stawać się one groźne dla naszego zdrowia i jakości życia.

\section{Stres akulturacyjny}

Sytuacje stresowe są nieodłącznym atrybutem życia człowieka, a współcześnie pojęcie stres na stałe zagościło w języku potocznym. W literaturze przedmiotu środowisko naukowe mimo powszechności tego zjawiska nie wypracowało do tej pory jednolitej definicji. Zagadnienie stresu jest obszarem wspólnych zainteresowań wielu badaczy z dziedziny psychologii, medycyny i socjologii.

Jako prekursora problematyki stresu wskazuje się na francuskiego fizjologa Claude’a Bernarda, który wyraził pogląd, że w organizmie istnieją mechanizmy obronne, których współdziałanie umożliwia mu zwalczanie zagrożeń, dzięki czemu utrzymuje się on przy życiu (Waszkowska, Potocka, Wojtaszczyk 2010). Po raz pierwszy definicja stresu została wprowadzona do literatury naukowej w latach 50. XX wieku przez Hansa Selyego, który terminem „stres” określił nieswoistą reakcję organizmu na wszelkie stawiane mu wymagania (Gerring, Zimbardo 2006).

Stres akulturacyjny, który zależny jest od subiektywnej oceny sytuacji, w większości przypadków mobilizuje cudzoziemców do tego, by podjęli jakikolwiek wysiłek w celu poradzenia sobie w nowych warunkach dotyczących odzyskania równowagi między wymaganiami otoczenia, a własnymi możliwościami oraz poprawy stanu emocjonalnego. W takim podejściu osoba traktuje stresor jak wyzwanie i dąży do poszukiwania informacji oraz rozwiązań. Wyzwala to wówczas motywację w kierunku zbliżenia się do napotkanej trudności i chęci zmierzenia się z nią w sposób konstruktywny. Natomiast osoba, która owładnięta jest lękiem, spostrzega stresor jako zagrożenie i bezpośrednia konfrontacja z nim może być dla niej zbyt trudna (Heszen-Niejodek 2007). Problem stresu akulturacyjnego pojawia się w sytuacji zmiany miejsca pobytu, który 
wywoływany jest przez czynniki zewnętrzne, związane z realiami nowego kraju pobytu. Jest zatem doświadczaniem przez emigranta różnorodnych trudności na pograniczu własnej i obcej kultury w postaci wewnętrznego napięcia i dyskomfortu, który wynika z dysproporcji między wymaganiami nowej sytuacji kulturowej, a jego kompetencjami adaptacyjnymi.

Autorka w trakcie przygotowania do pracy dyplomowej w roku 2017 przeprowadziła badania, w których diagnozowała sytuację polskich kobiet w związkach wielokulturowych w Wielkiej Brytanii w aspekcie stresu akulturacyjnego'1. Funkcjonują one często w sytuacji konieczności radzenia sobie zarówno z problemami dotyczącymi związku, jak i samą akulturacją. Badane kobiety odpowiadały na pytania dotyczące postrzegania przez nie kontaktów społecznych, ich kulturową adaptację w nowym kraju, miały określić swoje postawy i oczekiwania związane z nową kulturą, poczucie dyskryminacji, samoocenę i ocenę swojej życiowej satysfakcji oraz odczucia związane z własnymi problemami psychologicznymi.

Celem badań była próba odnalezienia tych elementów, które wywołują stres akulturacyjny polskich kobiet w związkach wielokulturowych. Praktycznym celem opisanych badań było zebranie informacji dotyczących stresu akulturacyjnego, a na tej podstawie określenie ich sytuacji społecznej w grupie etnicznej, narodowej oraz wskazanie na zjawisko kulturowej identyfikacji. Istotą badań stało się ustalenie obrazu strategii akulturacji związanej z postawami i oczekiwaniami Polek wobec danej kultury. Następnym krokiem było wskazanie poziomu ich samooceny, życiowej satysfakcji, psychologicznych problemów oraz kompetencji społeczno-kulturowych.

Wyniki badań ukazują, iż stres związany z akulturacją ma wpływa na funkcjonowanie polskich kobiet w związkach wielokulturowych.

${ }^{1}$ W tekście wykorzystano jej fragmenty: Urszula Walczak (2017), Stres akulturacyjny polskich kobiet w zwiq̨zkach wielokulturowych mieszkających w Wielkiej Brytanii, Polski Uniwersytet na Obczyźnie, Londyn, praca napisana pod kierunkiem dr Grażyny Czubińskiej. 
W kontekście procesu akulturacji stwierdza się zróżnicowany charakter postaw polskich kobiet, ich poglądów, zachowań, emocji czy problemów psychologicznych. Płaszczyzna kontaktów społecznych ukazuje istotę podtrzymywania kontaktów między grupą etniczną a narodową. Istotna okazuje się także korelacja zachodząca między językiem etnicznym, a narodowym. Niejednokrotny brak zdecydowanego podejścia do własnej samooceny może świadczyć o braku wsparcia czy też pozytywnego utwierdzania, wzmacniania ze strony partnera w różnorodnych przedsięwzięciach podejmowanych przez te kobiety.

Taka sytuacja wpływa na poziom satysfakcji życiowej polskich kobiet w związkach wielokulturowych. Wyczuwalny jest brak ich pewności i wiary we własne możliwości, co wynika z neutralnej postawy czy też ograniczeń, jakie wyznacza im otocznie, partner, a nawet sama kobieta. Skutkuje to różnorodną częstotliwością występowania problemów fizjologicznych, (zmęczenie, zawroty głowy, osłabienie, rozdrażnienie) oraz psychologicznych (poczucie smutku, osamotnienia, brak spójności myśli, zamartwianie się, brak motywacji do działania oraz podtrzymywania lub rozwijania dotychczasowych zainteresowań czy pasji).

Podsumowanie

Związki mieszane wzbudzają wiele kontrowersji i pytań. Czy są trudniejsze niż związki osób pochodzących z tego samego kraju? Czy przynoszą więcej problemów? Na te pytania mogą odpowiedzieć wyłącznie osoby tworzące takie związki. Nie ulega natomiast wątpliwości, że w tych związkach pojawia się stres akulturacyjny, który uwarunkowany może być narodowością partnera, jego ojczystym językiem, religią, kulturą czy kolorem skóry.

Społeczeństwo wielokulturowe staje się codziennością u podstaw której leżą różnice stanowiące o źródłach różnorodnych konfliktów. Emigranci, którzy posiadają potrzebę przynależności do danej grupy 
narodowej oraz potrzebę wsparcia, rozwijają swoją tożsamość dwukulturową oraz wykazują większą tendencję do tworzenia związków mieszanych. Konieczność zaadaptowania się do nowych warunków powoduje u nich nie tylko stres, ale wyzwala także pewną motywację do utrwalania relacji, uczy wzajemnej tolerancji, a także sprzyja wzajemnemu kulturowemu zbliżaniu się partnerów w procesie wyrównywania różnic.

Polskie kobiety w związkach wielokulturowych mieszkające w Wielkiej Brytanii odczuwają różnorodne problemy związane ze swoim zdrowiem psychicznym, fizjologicznym, czy emocjonalnym. Ich związki podatne są na kryzysy, co często wynika z braku posiadania przez nie umiejętności realizowania zadań rozwojowych i zaspokajania swoich potrzeb w procesie adaptacji kulturowej. Ich równowaga emocjonalna bywa zachwiana, ponieważ nie otrzymują wsparcia od partnera w rozwiązaniu problemów czy w zaspokajaniu potrzeb. Konsekwencją takiej sytuacji jest brak samoakceptacji oraz wiary w swoje możliwości. Potrzebują wówczas pomocy w doskonaleniu swoich umiejętności, które niezbędne są do realizacji potrzeb i zadań, oraz wsparcia od partnera, rodziny czy przyjaciół. Niezastąpionym wsparciem jest jednak partner oraz jego właściwa postawa emocjonalna wobec partnerki.

Zrozumienie zjawiska stresu jest koniecznością dla wszystkich osób, które żyją w związkach wielokulturowych. Niezależnie bowiem od reprezentowanego przez nie stanowiska, często dochodzi do konfrontacji z wymaganiami lub zmianami na różnych płaszczyznach, które zmuszają je do poradzenia sobie z nimi lub zaadaptowania się do nowych warunków. Poza wiedza o mechanizmach stresu konieczne jest również posiadanie doraźnych umiejętności przeciwdziałania jego skutkom oraz przyjmowanie zaawansowanych strategii postępowania, które nie dopuszczają do ponoszenia długotrwałych i wysokich kosztów życia w stresującym środowisku. 
Literatura

Anderson B. (2000), Doing dirty work? The globalpolitics of domestic labour, Zed Books, New York

Balzani M. (2006), Transnational marriage among Ahmadi Muslims in the UK, "Global Networks" Vol. 6, Iss. 4

Bera R. (2011), Emigranci polscy $w$ nowym środowisku pracy, UMCS, Lublin

Bera R., Korczyński M. (2012), Dystans społeczny emigrantów polskich wobec „obcych” $i$,innych”, UMCS, Lublin

Berry J.W. (1995), Psychology of acculturation, [w:] The culture and psychology reader, (red.) Goldberger N.R., Veroff J.B., University Press, New York

Berry J.W. (1997), Immigration, Acculturation, and Adaptation, “Applied Psychology: An International Review" Vol. 46, Iss. 1

Berry J.W. (2003), Conceptual approaches to acculturation, [w:] Acculturation. Advances in theory, measurement and applied research, (Eds.) Chun K.W., Balls-Organista P.M., Marin G., American Psychological Association Press, Washington

Berry J.W., Sam D.L. (2006), The Cambridge handbook of acculturation psychology, Cambridge University Press, New York

Bokszański Z. (1989), Tożsamość, interakcja, grupa: tożsamość jednostki $w$ perspektywie socjologicznej, Wydawnictwo Uniwersytetu Łódzkiego, Łódź

Boski P. (2010), Kulturowe ramy zachowań społecznych. Podręcznik psychologii międzykulturowej, Wydawnictwo Naukowe PWN, Warszawa

Brzozowska A. (2015), Dobór małżeński i integracji imigrantów w matżeństwach mieszanych - stan badań, „CMR Working Paper” nr 81 (139), Ośrodek Badań nad Migracjami Uniwersytetu Warszawskiego, Warszawa 
Chutnik M. (2007), Szok kulturowy. Przyczyny. Konsekwencje. Przeciwdziałanie, Universitas, Kraków

Deszczyński P. (2011), Conceptualization of globalization, [w:] Globalization, (Ed.) Deszczyński P., WSB, Poznań

Filipek A. (2008), Tożsamość jako istotny element kultury bezpieczeństwa, [w:] Bezpieczeństwo człowieka a wielokulturowość, (red.) Dębowski J., Jarmoch E., Świderski A.W, Uniwersytet PrzyrodniczoHumanistyczny w Siedlcach, Siedlce

Garapich M. (2008), The Migration Industry and Civil Society: Polish Immigrants in the United Kingdom before and after EU Enlargement, "Journal of Ethnic and Migration Studies" Vol. 34, No 5

Gerring R.J., Zimbardo P.G. (2006), Psychologia i życie, Wydawnictwo Naukowe PWN, Warszawa

Ghosh J. (2009), Migration and gender empowerment: recent trends and emerging issues, "Human Development Research Paper" No. 4 Global Perspectives on Migration and Development. GFMD Puerto Vallarta and Beyond (2012), (Ed.) Omelaniuk I., Springer Netherlands, Heidelberg

Główny Urząd Statystyczny (2011), Narodowy Spis Powszechny, http://stat.gov.pl/spisy-powszechne/nsp-2011/[05.02.2018]

Grzymała-Kazłowska A. (2013), Zarys koncepcji społecznego zakotwiczenia. Inne spojrzenie na tożsamość, adaptację i integrację imigrantów, „Kultura i Społeczeństwo” tom 57, nr 3

Grzymała-Moszczyńska J. (2011), Dwie kultury, jedna miłość? Zjawisko związków międzykulturowych, [w:] Cóż wiemy o miłości?, (red.) Żebrowski M., Nomos, Kraków

Heszen-Niejodek I. ( 2007), Teoria stresu psychologicznego i radzenia sobie, [w:] Psychologia. Podręcznik akademicki, (red.) Strelau J., tom 3, Gdańskie Wydawnictwo Psychologiczne, Gdańsk 
International Organization for Migration - Slovak Republic (b.r.), $M i$ gration in the world, https://www.iom.sk/en/migration/migrationin-the-world.html [30.04.2019]

International Organization for Migration (2015), World Migration Report 2015, Geneva, https://www.iom.int/world-migration-report2015 [12.02.2108]

Jodłowska-Herudzińska M. (2002), Kwestie doboru małżeńskiego $w$ międzykulturowych małżeństwach mieszanych. Życie rodzinneuwarunkowania makro i mikrostrukturalne, „Roczniki Socjologii Rodziny" tom XIV

Kawczyńska-Butrym Z. (2009), Migracje. Wybrane zagadnienia, UMCS, Lublin

Kim M. (2010), Gender and international marriage migration, "Sociology compass" Vol. 9, Iss. 4

Kluź A. (2001), Zmiany i stałość w tożsamości pod wpływem emigracji i pobytu w Polsce, [w:] O akulturacji imigrantów w Polsce, (red.) Malewska-Peyre H., PAN, Warszawa

Kubitsky J.(2012), Psychologia migracji, Difin, Warszawa

Kyzyma I. (2007), Female Migration in Ukraine: Determinants and Consequences, https://www.hse.ru/data/378/614/1238/kyzyma-pa per.pdf [06.02.2018]

Łodzin’ ski S., Grzymała-Kazłowska A., (2011), Koncepcje, badania i praktyki integracji imigrantów. Dos' wiadczenia polskie w europejskim konteks'cie, „Studia Migracyjne - Przegląd Polonijny” nr 2

Lutz H. (2004), Life in the Twilight Zone: Migration, Transnationality and Gender in the Private Household, "Journal of Contemporary European Studies” Vol. 12, No. 1

Mały stownik stosunków międzynarodowych (1996), (red.) Michałowska G., WSiP, Warszawa

Mamzer H. (2003), Tożsamość w podróży. Wielokulturowość a ksztattowanie tożsamości jednostki, UAM, Poznań, 
Martin S.F. (2007), Women, Migration and Development, "Transatlantic Perspectives on Migration” Policy Brief \#1, Institute for the Study of International Migration Walsh Scholl of Foreign Service, Georgetown University, Washington

Miłkowski T. (1997), Kobiety we wspótczesnych migracjach, [w:] Migracje $i$ społeczeństwo, (red.) Zamojski J., t. 2, Instytut Historii PAN, Warszawa

Mostwin D. (1991), Emigranci polscy $w$ USA, KUL, Lublin

Niedomysl T., Osth J., van Ham M. (2010), The Globalisation of Marriage Fields: The Swedish Case, "Journal of Ethnic and Migration Studies" Vol. 36, Iss. 7

Paleczny T. (2007), Interpersonalne stosunki międzykulturowe, Wydawnictwo Uniwersytetu Jagiellońskiego, Kraków

Pasamonik B.(2008), Imigrantki $w$ społeczeństwach Zachodu. Emancypacja i integracja, „Kultura i społeczeństwo” nr 2

Perrin N., Rajabaly H.(2005), Polish women in Belgium:from immigrant strategies to migration statistics, [w:] International migration. A multidimensional analysis, (Ed.) Slany K., AGH University of Science and Technology Press, Cracow

Rajkiewicz A. (2009), Polskie matżeństwa binacjonalne. Materiaty, „Migracje zagraniczne a polityka rodzinna. Biuletyn Rzecznika Praw Obywatelskich" zeszyt 66

Remmenick L. (2009), Exploring Intercultural Relationships. A Study of Russian Immigrants Married to Native Israelis, "Journal of Comparative Family Studies" Vol. 40, Issue 5

Roca J., Urmeneta A. (2013), Bi-national Weddings in Spain: A Recent and Increasingly Frequent Phenomenon in the Context of the Globalization of the Marriage Market, "Procedia Social and Behavioral Sciences" Vol. 82

Sadowski A. (1999), Zróżnicowanie kulturowe a społeczeństwo obywatelskie, „Sprawy Narodowościowe” nr 14-15 
Sakson B. (2001), Źródło pionierskiego łańcucha migracyjnego, [w:] Ludzie na huśtawce. Migracje między peryferiami Polski i Zachodu, (red.) Jaźwińska E., Okólski M., Warszawa, Scholar

Schmoll C. (2008), Moving on their own? Mobility Strategies and Social Networks of Migrant Women from Maghrebin in Italy, https://halshs.archives-ouvertes.fr/halshs-00212030/document [06.02.2018]

Slany K., Małek A. (2005), Female migration from Poland during the period of the systemic transformation (on the basis of the migration from Poland to the USA and Italy), [w:] International migration. A multidimensional analysis, (Ed.) Slany K., AGH University of Science and Technology Press, Cracow

Szczygielska I. (2013), Migracje zarobkowe kobiet oraz ich wptyw na funkcjonowanie rodzin, Wydawnictwo Uniwersytetu Warszawskiego, Warszawa

Vaiou D. (2002), In the interstices of the city: Albania women in Athens, "In Escape, Popilations, Societes" No. 3

Wallas M. (2008), Dialog międzykulturowy - szanse i ograniczenia, [w:] Drogi i bezdroża komunikacji, (red.) Bering P., Łukomski G., Collegium Europaeum Gnesnense, Gniezno

Ward C., Furnham A., Bochner S. (2001), The psychology of culture shock, Routledge Taylor \& Francis Group, Hove

Waszkowska M., Potocka A., Wojtaszczyk P. (2010), Miejsce pracy na miarę oczekiwań. Poradnik dla pracowników socjalnych, Instytut Medycyny Pracy im. prof. J. Nofera, Łódź

Witkowska A. (1997), Cześć i skandale. O emigracyjnym doświadczeniu Polaków, Słowo/Obraz Terytoria, Gdańsk 